\title{
PEMBELAJARAN KONVENSIONAL DAN KRITIS KREATIF DALAM PERSPEKTIF PENDIDIKAN ISLAM
}

\author{
Fahrudin $^{1}$, Ansari', Ahmad Shofiyuddin Ichsan ${ }^{3}$
}

\footnotetext{
${ }^{1}$ Universitas Islam Negeri Mataram, ${ }^{2}$ Universits Islam Negeri Sunan Kalijaga Yogyakarta, ${ }^{3}$ Institut Ilmu Al-Qur'an An Nur Yogyakarta

J1. Pendidikan No.35 Dasan Agung Baru, Kota Mataram, Nusa Tenggara Barat

e-mail: $\underline{\text { ahru406@gmail.com, ansarisanusin212@gmail.com, ahmad.shofiyuddin.ichsan@ gmail.com }}$
}

\begin{abstract}
Abstrak: Penelitian ini bertujuan untuk mengetahui perspektif pendidikan Islam tentang pembelajaran konvensional dan pembelajaran kritis kreatif. Penelitian ini menggunakan metode library research, dan pengumpulan data menggunakan metode dokumentasi. Analisa datanya menggunakan teknik komparasi, yaitu menganalisis tentang landasan filosofis pembelajaran konvensional dan pembelajaran kritis kreatif serta memandang kedua konsep pembelajaran tersebut dengan menggunakan perspektif pendidikan Islam. Hasil penelitian menjelaskan bahwa pendidikan Islam adalah proses mengubah tingkah laku individu pada kehidupan pribadi dan masyarakat melalui proses pembelajaran dengan upaya membantu mengembangkan peserta didik menjadi lebih maju berlandaskan nilai-nilai yang baik dalam kehidupannya, sehingga terbentuk pribadi insan kamil, baik berkaitan dengan akal, perasaan, dan perbuatan. Kedua model pembelajaran di atas sangat berbeda secara konsep, sehingga perlu ada upaya penyatuan yang kreatif dari seorang guru sebagai pengatur dalam proses pembelajaran. Maka dari itu, kedua model pembelajaran tersebut dapat berguna sesuai dengan kondisi dan situasi, sehingga tidak ada yang perlu dihilangkan antara model pembelajaran konvensioal dan kritis kreatif. Bahkan pembelajaran dengan model demikian sangat sesuai dengan masa kekinian.
\end{abstract}

Kata Kunci : Pendidikan Islam, Pembelajaran Konvensional, Kritis kreatif

\begin{abstract}
This research aims to determine the perspective of Islamic education about conventional learning and critical creative learning. This research is library research and data collection uses documentation method. The data analysis uses a comparative technique, namely researching the philosophical foundations of conventional learning and critical-creative learning and looking at the two learning concepts using the perspective of Islamic education. Islamic education is the process of changing individual behavior in personal life and society through the learning process with an effort to help develop students to be more advanced based on good values in their lives, so that personal human beings are formed, both related to reason, feelings, and actions. The results of this research indicate that the two learning models above are very different conceptually, so there needs to be a creative unification effort from a teacher as a regulator in the learning process. Therefore, the two learning models could be useful according to the conditions and situations, so that there is no need to eliminate the conventional and critical creative learning models. Even learning with this model is very appropriate to the present.
\end{abstract}

Keywords: Islamic Education, Conventional Learning, Critical Creative 
Hikmah, Vol. 18, No. 1, Januari-Juni 2021, p-ISSN: 1829-8419 e-ISSN: 2720-9040

\section{PENDAHULUAN}

Secara alamiah, manusia tumbuh dan berkembang sejak dalam kandungan sampai meninggal, mengalami proses tahap demi tahap. Pola perkembangan manusia yang berproses demikian, berlangsung di atas hukum alam yang ditetapkan oleh Allah sebagai sunnatullah. Pendidikan Islam sebagai usaha membina dan mengembangkan pribadi manusia (peserta didik), dalam aspek rohaniah dan jasmaniah juga harus berjalan secara bertahap (Muzayyin Arifin, 2014). Pendidikan Islam merupakan pendidikan yang bertujuan untuk membentuk pribadi muslim seutuhnya, mengembangkan seluruh potensi manusia baik yang berbentuk jasmaniyah maupun rohaniyah, menumbuh suburkan hubungan yang harmonis setiap pribadi manusia dengan Allah, manusia dengan manusia, dan manusia dengan alam semesta.

Untuk itu, pembelajaran pendidikan Islam hendaknya menyediakan jalan untuk pertumbuhan manusia dalam segala aspeknya, seperti spritual, intelektual, imaginatif, baik secara individual maupun secara kolektif dan memotivasi semua aspek untuk mencapai kebaikan dan kesempurnaan. Sedangkan Naquib Al-Attas yang dikutip oleh Kemas Badaruddin menyatakan bahwa pembelajaran pendidikan Islam adalah usaha yang dilakukan oleh guru terhadap peserta didik untuk pengenalan dan pengakuan tempattempat yang benar dari segala sesuatu dari tatanan penciptaan sehingga membimbing mereka ke arah tatanan wujud dan kepribadian. (Gozali \& Tamrin, 2020). Di sini, Al-Attas merekomendasikan untuk pembenahan dan penyempurnaan pendidikan Islam, salah satunya gagasan islamisasi ilmu pengetahuan (Fahrudin \& Ahmad Shofiyuddin Ichsan, 2020).

Untuk dapat menghasilkan out put seperti diinginkan oleh pendidikan Islam di atas, maka harus melewati proses tahap demi tahap (pembelajaran). Oleh karenanya, pembelajaran merupakan suatu aktivitas (proses) sistematis yang terdiri atas banyak komponen. Masing-masing komponen tidak bersifat parsial, tetapi harus berjalan secara teratur, saling bergantung, komplementer, dan berkelanjutan. Untuk itu, diperlukan pengelolaan pembelajaran yang baik yang harus dikembangkan berdasarkan pada asas pembelajaran.

Secara teoritis, tujuan dan model pendidikan seperti yang diungkapkan di atas sangatlah ideal. Namun, harus jujur diungkapkan bahwa sejauh ini, kondisi ril pendidikan di negeri ini sungguh sangat memprihatinkan, dapat dirasakan di setiap jenjang dan jenis pendidikan. Apalagi jika kita melihat kondisi pendidikan di berbagai daerah terpencil, pedalaman atau pesisir, bagaimana anak usia sekolah yang seharusnya memiliki hak untuk mengenyam pendidikan yang layak ternyata jauh dari harapan. (Adnan, 2015).

Sulitnya akses pendidikan bagi masyarakat terpencil, pedalaman dan pesisir menjadi pekerjaan rumah bagi bangsa Indonesia yang sampai saat ini masih belum seutuhnya dapat diatasi. Belum lagi biaya pendidikan yang kian tahun semakin bertambah, membuat masyarakat berekonomi rendah tidak dapat menikmati dunia pendidikan. (Mesiono \& Haidir, 
2021). Sehingga wajar jika masih banyak kalangan yang belum puas dengan kualitas pendidikan di negeri ini. Komentarkomentar yang bernada sinis selalu saja ditujukan kepada persoalan kualitas pendidikan, seolah-olah pendidikan yang telah berjalan cukup lama ini belum memberikan hasil yang optimal, memuaskan, dan belum memberikan makna terhadap peningkatan mutu di setiap jenjang dan jenis pendidikan. (Umam, 2019).

Perubahan memang perlu untuk dilakukan, khususnya dalam menghadapi dunia global. Hal tersebut dengan cara merubah yang kira-kira berkaitan dengan mengapa persoalan pendidikan masih saja menjadi tema yang menarik untuk dibicarakan, mengapa mutu pendidikan merosot? Mengapa pendidikan di Indonesia tidak berkualitas? mengapa pendidikan di Indonesia sudah ketinggalan jauh dari Negara lain? mengapa pendidikan nasional kita masih stagnan? di mana titik perhatiannya adalah pada proses pembelajaran. Apa yang perlu diubah, apa yang perlu dipersiapkan, apa yang perlu dibenahi, komponen-komponen apa yang perlu ada, dan lain sebagainya. Maka sederet pertanyaan ini perlu dijawab oleh para praktisi pendidikan dan seluruh elemen yang memiliki kapasitas serta tanggung jawab dalam memberikan jalan alternatif di tengah suramnya dunia pendidikan dewasa ini. (Zainuddin, 2014).

Oleh karena itu, menurut peneliti sangat penting untuk dipahami secara mendalam bagaimana karakteristik dari konsep pembelajaran konvensional dan pembelajaran kritis kreatif. Karena salah satu di antara problem pendidikan nasional dewasa ini adalah minimnya pemahaman guru terhadap model-model pembelajaran yang mengakibatkan adanya miskomunikasi antara guru dan peserta didik dikarenakan guru memaksakan sistem pembelajaran yang mungkin saja tidak sesuai dengan karakter belajar peserta didik. Sehingga dalam konteks itu, peneliti tertarik untuk mengkaji lebih mendalam dengan mengunakan perspektif pendidikan Islam melalui proses penelitian ini. Penelitian ini diharapkan dapat berkontribusi bagi dunia pendidikan, terutama terkait pengetahuan guru terhadap konsep pendidikan Islam, model pembelajaran konvensional, dan kritis kreatif.

Terkait dengan penelitian ini terdapat beberapa penelitian yang relevan dengan penelitian ini di antaranya perbandingan pembelajaran PAI cooperative dengan konvensional (Azmi, 2012), Pembelajaran berbasis masalah untuk meningkatkan daya kritis siswa (Sunaryo, 2014), Model pembelajaran konvensional pada ilmu Ushul fikih (Sapiudin et al., 2016), model-model pembelajaran inovatif dan kontekstual (Marzuki, 2017), Penerapan pembelajaran aktif, inovatif, kreatif, efektif, dan menyenangkan (Khasanah, 2017). Dari beberapa penelitian tersebut tampak ruang kosong pembahasan yakni komparasi antara pembelajaran konvensional dengan krtiskreatif.

\section{METODE PENELITIAN}

Pendekatan yang digunakan dalam penelitian ini yaitu kajian pustaka (library research) yang merupakan serangkaian 
Hikmah, Vol. 18, No. 1, Januari-Juni 2021, p-ISSN: 1829-8419 e-ISSN: 2720-9040

kegiatan yang berkenaan dengan metode pengumpulan data pustaka, membaca, mencatat, serta mengolah bahan koleksi perpustakaan secara mendalam tanpa memerlukan riset lapangan. Kajian pustaka merupakan metode pengumpulan data yang diarahkan kepada pencarian data dan informasi melalui dokumen-dokumen, baik dokumen tertulis, foto-foto, gambar, maupun dokumen elektronik yang dapat mendukung dalam proses penelitian. Hasil penelitian juga akan semakin kredibel apabila didukung foto-foto atau karya tulis akademik dan seni yang telah ada (Sugiyono, 2016).

Kajian pustaka ini dilakukan dengan cara mengumpulkan data atau informasi dari berbagai sumber atau ide-ide untuk penggalian pemikiran atau gagasan baru sebagai bahan dasar untuk melakukan deduksi dari pendidikan kritis kreatif yang telah ada sehingga kerangka sebagai gagasan baru dapat dikembangkan atau untuk mengembangkan upaya pemecahan masalah pendidikan yang ada.

\section{HASIL DAN PEMBAHASAN}

Secara terminologis, para ahli memberikan beragam pendapat dalam memaknai pendidikan Islam, di antaranya: Muhammad Fadhil Al-Jamali berpendapat bahwa pengertian pendidikan Islam adalah upaya mengembangkan, mendorong, serta mengajak manusia lebih maju dengan berlandaskan nilai-nilai yang tinggi dan kehidupan yang mulia, sehingga terbentuk pribadi yang lebih sempurna, baik yang berkenaan dengan akal, perasaan, maupun perbuatan (Muhammad Munif, 2016).
Menurut Omar Mohammad AtToumi Asy-Syaibani seperti yang dikutip oleh Bukhari Umar ia mendefinisikan bahwa "Pendidikan Islam adalah proses mengubah tingkah laku individu pada kehidupan pribadi, masyarakat, dan alam sekitarnya dengan cara pengajaran sebagai suatu aktivitas asasi dan sebagai profesi di antara profesi-profeis asasi dalam masyarakat" (Faizal Djabidi, 2016).

Pengertian tersebut memfokuskan perubahan tingkah laku manusia yang konotasinya pada pendidikan etika. Selain itu, pengertian tersebut menekankan pada aspek-aspek produktivitas dan kreativitas manusia dalam peran dan profesinya dalam kehidupan bermasyrakat. Dengan demikian, jelaslah bahwa proses pendidikan Islam merupakan rangkaian usaha membimbing, mengarahkan potensi hidup manusia yang berupa kemampuan-kemampuan dasar dan kemampuan belajar, sehingga terjadilah perubahan dalam kehidupan pribadinya sebagai makhluk individu dan sosial serta dalam hubungannya dengan alam sekitar di mana ia hidup. Istilah membimbing dan mengarahkan mengandung pengertian bahwa usaha mempengaruhi jiwa anak didik melalui proses setingkat demi setingkat menuju pembentukan manusia yang berpribadi dan berbudi luhur sesuai dengan ajaran Islam (Huda, 2015).

\section{Pembelajaran Konvensional}

Pembelajaran konvensional dapat diartikan sebagai sikap dan cara berpikir serta bertindak yang selalu berpegang teguh pada norma dan adat kebiasaan yang ada secara turun temurun (Hidayatullah, 2015). 
Oleh karena itu, model pembelajaran konvensional dapat juga disebut sebagai konsep pembelajaran tradisional.

Pengertian di atas disimpulkan bahwa konsep pembelajaran konvensional adalah suatu pembelajaran yang mana dalam proses belajar mengajar dilakukan sangat monoton dan verbalis, yaitu dalam penyampaian materi pelajaran masih mengandalkan ceramah atau dalam istilah yang digunakan dalam penelitian ini adalah sebuah proses belajar mengajar yang berpusat pada guru. Lebih dari itu, model dari pembelajaran konvensional (baca: tradisional) adalah metode mengajar yang lazim dipakai oleh guru sejak dulu (Sahkholid Nasution, 2012).

Proses belajar mengajar dalam pembelajaran konvensional umumnya berlangsung satu arah yang merupakan transfer atau pengalihan pengetahuan, informasi, norma, nilai, dan lain-lainnya dari seorang pengajar kepada peserta didik. Proses semacam ini dibangun dengan asumsi bahwa peserta didik ibarat botol kosong atau kertas putih. Guru atau pengajarlah yang harus mengisi botol tersebut atau menulis apapun di atas kertas putih tersebut. Sistem seperti ini disebut banking concept (Helmiati, 2016).

Sejalan dengan pandangan di atas, Van de Walle menyatakan bahwa "guru tradisional masih menuntun peserta didik bagaimana menggunakan materi yang dipelajari untuk mengerjakan latihan. Fokus utama dari pelajaran adalah mendapatkan jawaban" (Zikri, 2016). Para peserta didik menyandarkan pada guru untuk menentukan apakah jawabannya benar. Anak-anak yang mendapatkan pengalaman seperti ini akan mempunyai pandangan yang sempit. Akibatnya, peserta didik dijauhkan dari sumber pengetahuan yang sebenarnya sangat baik.

Menurut Subiyanto bahwa pembelajaran konvensional mempunyai ciriciri, yaitu: Pertama, peserta didik tidak mengetahui tujuan mereka belajar pada hari itu. Kedua, guru biasanya mengajar dengan berpedoman pada buku. Ketiga, tes atau evaluasi biasanya bersifat sumatif dengan maksud untuk mengetahui perkembangan siswa. Keempat, peserta didik harus mengikuti cara belajar yang dipilih oleh guru dengan patuh mempelajari urutan yang diterapkan dan kurang sekali mendapatkan kesempatan untuk menyatakan pendapatnya. (Rahardjo, 2015).

Sedangkan menurut Philip R. Wallace, pendekatan pembelajaran dikatakan sebagai pendekatan pembelajaran yang konvensional jika mempunyai ciri-ciri: Pertama, otoritas seorang guru lebih diutamakan dan berperan sebagai contoh bagi peserta didiknya. Kedua, perhatian kepada masing-masing individu atau minat sangat kecil. Ketiga, pembelajaran di sekolah lebih banyak dilihat sebagai persiapan akan masa depan, bukan sebagai peningkatan kompetensi peserta didik di saat ini. Keempat, penekanan yang mendasar adalah pada bagaimana pengetahuan dapat diserap oleh peserta didik dan penguasaan pengetahuan tersebutlah yang menjadi tolak ukur keberhasilan tujuan, sementara pengembangan potensi peserta didik terabaikan (Siregar, 2019). 
Hikmah, Vol. 18, No. 1, Januari-Juni 2021, p-ISSN: 1829-8419 e-ISSN: 2720-9040

Jika dilihat tiga jalur model penyampaian pesan pembelajaran, penyelenggaraan pembelajaran konvensional lebih sering menggunakan pemberian informasi di bandingkan dengan memperagakan dan memberikan kesempatan untuk menampilkan unjuk kerja secara langsung. Dengan kata lain, guru lebih sering menggunakan strategi atau metode ceramah dengan mengikuti urutan materi dalam kurikulum secara ketat. Guru berasumsi bahwa keberhasilan program pembelajaran dilihat dari ketuntasannya menyampaikan seluruh meteri yang ada dalam kurikulum.

Berdasarkan penjelasan di atas, pendekatan konvensional dapat dimaklumi sebagai pendekatan pembelajaran yang lebih banyak berpusat pada guru, komunikasi lebih banyak satu arah dari guru ke peserta didik, metode pembelajaran lebih pada penguasaan konsep-konsep bukan kompetensi. Tidak hanya itu, peserta didik secara pasif menerima informasi, pembelajaran sangat abstrak dan teoritis serta tidak bersandar pada realitas kehidupan, memberikan hanya tumpukan beragam informasi kepada peserta didik, cenderung fokus pada bidang tertentu, waktu belajar peserta didik sebagaian besar digunakan untuk mengerjakan buku tugas, mendengar ceramah guru, dan mengisi latihan (kerja individual).

Kemudian terkait dengan komponen pembelajaran dapat dikelompokkan dalam tiga kategori utama, yaitu: guru, isi atau materi pembelajaran, dan peserta didik. Interaksi antara tiga komponen utama melibatkan tujuan pembelajaran, metode pembelajaran, media pembelajaran, dan evaluasi pembelajaran, sehingga tercipta situasi pembelajaran yang memungkinkan terciptanya tujuan yang telah direncanakan sebelumnya.

- Peserta didik

Pembelajaran konvensional memandang keberadaan peserta didik ibarat gelas kosong yang hanya siap dituangkan air. Peserta didik dipandang sebagai manusia yang tidak memiliki kemampuan-kemampuan atau potensipotensi untuk dikembangkan secara mandiri lewat usaha yang dilakukanya. Dalam istilah yang lain, pembelajaran konvensional masih memandang peserta didik sebagai objek yang pasif sekaligus penurut atas semua perlakuan dari seorang guru. (Lubis, 2016) Mestinya, peserta didik tidak hanya berfungsi sebagai pendengar sekaligus penerima secara langsung pesan dari setiap materi yang disampaikan oleh seorang guru, tetapi lebih dari itu (Bashori, 2016).

Banyak yang menganggap bahwa peserta didik dianggap menjadi bejanabejana atau wadah kosong untuk diisi oleh seorang guru. (Nurzakiyah, 2017). Artinya, semakin penuh guru mengisi wadah-wadah itu, semakin baik pula seorang guru, sehingga dalam proses pembelajaran yang berwatak konvensional seperti ini, yang terjadi bukanlah proses komunikasi dua arah antara guru dan peserta didik, tetapi guru menyampaikan pernyataanpernyataan dan mengisi tabungan yang kosong, yang diterima, dihafal, dan 
diulangi dengan patuh oleh para peserta didik.

- Materi Pembelajaran

Dalam pembelajaran konvensional, guru masih menggantungkan pada buku teks, materi yang disampaikan sesuai dengan urutan isi buku teks (Sanjaya \& Budimanjaya, 2017). Yang diharapkan peserta didik memiliki pandangan yang sama dengan guru atau sama dengan buku teks tersebut. Berbagai alternatif perbedaan interpretasi di antara peserta didik terdapat fenomena sosial yang kompleks tidak dipertimbangkan. Peserta didik belajar dalam isolasi yang mempelajari kemampuan tingkat rendah dengan cara melengkapi buku tugasnya setiap hari.

- Guru

Guru dilihat sebagai sosok yang kharismatik, karena jasanya yang banyak mendidik umat manusia dari dulu sampai saat ini. Dalam bahasa Jawa, guru sendiri bermakna "digugu lan ditiru" (Rustam \& Ahmad Shofiyuddin Ichsan, 2020). E. Mulyasa juga menegaskan bahwa bahwa guru memiliki andil yang sangat besar terhadap keberhasilan pembelajaran di sekolah (E. Mulyasa, 2007:53). Minat, bakat, kemampuan, dan potensi-potensi yang dimiliki oleh peserta didik tidak akan berkembang secara optimal tanpa bantuan seorang guru. Atas dasar asumsi di atas, pembelajaran konvensional lebih menekankan pada otoritas guru dalam pembelajaran. Peran guru dalam pembelajaran konvensional telah disempitkan hanya sebatas objek yang memberikan sesuatu kepada peserta didik, bahkan keberadaan guru dalam mempersiapkan materi pelajaran sangat terbatas sebagai bahan ceramah.

- Tujuan Pembelajaran

Pembelajaran konvensional memandang bahwa tujuan pembelajaran merupakan rumusan secara terperinci apa saja yang harus dikuasai oleh peserta didik sesudah melewati kegiatan pembelajaran atau hanya menekankan pada penambahan pengetahuan (Asri Budiningsih, 2015). Tujuan pembelajaran konvensional seperti yang diuraikan di atas tidak lepas dari keinginan mulia, yaitu untuk bagaimana peserta didik harus mampu menangkap apa saja ilmu yang ditransfer oleh seorang guru waktu dalam proses belajar mengajar. Lebih dari itu, tujuan akhir yang diharapkan dalam proses pembelajaran konvensional semata-mata terciptanya peserta didik yang mampu menguasai setiap materi pembelajaran yang telah dilalui olehnya ketika dalam ruangan kelas.

- Metode Pembelajaran

Metode pembelajaran yang dikenal dalam pembelajaran konvensional lebih banyak berpusat pada guru (Prasetyasni; Hadi; Marimin, 2012). Umumnya berlangsung satu arah yang merupakan transfer atau pengalihan pengetahuan, informasi, norma, nilai dari seorang pengajar kepada peserta didik (Helmiati, 2016). Dalam pelaksanaannya, guru menyajikan fakta-fakta dan menjelaskan konsep yang menjadi bahan pelajaran, sementara peserta didik hanya memiliki 
Hikmah, Vol. 18, No. 1, Januari-Juni 2021， p-ISSN: 1829-8419 e-ISSN: 2720-9040

kesempatan untuk menerima, mencatat, menyimak, dan menghafal apa yang dijelaskan oleh gurunya.

- Media Pembelajaran

Keberadaan media sangatlah terbatas jumlahnya dalam pembelajaran konvensional, karena yang menjadi tulang punggung kegiatan instruksional di sini adalah pengajar atau guru. Pengajar menyajikan isi pelajaran dengan urutan model, media dan waktu yang telah ditentukan dalam strategi instruksional. (Ridwan et al., 2015). Kegiatan instruksional ini berlangsung dengan menggunakan pengajar sebagai satu-satunya sumber belajar sekaligus bertindak sebagai penyaji isi pelajaran, padahal sumber belajar sendiri dapat beraneka ragam di lingkungan sekitar (Manurung, 2020). Pelajaran ini tidak menggunakan bahan ajar yang lengkap.

Dalam istilah Wina Sanjaya, media dalam pembelajaran konvensional tidak digunakan secara optimal hanya saja media yang digunakan oleh guru adalah berupa buku ajar dan berupa garis besar isi dan jadwal yang disampaikan diawali pembelajaran, beberapa transparansi dan formulir isian untuk dipergunakan sebagai latihan selama proses pembelajaran.

- Evaluasi Pembelajaran

Adapun dalam pembelajaran konvensional, keberadaan evaluasi hanya sebatas aktivitas yang menekankan pada respon pasif, keterampilan secara terpisah, dan biasanya mengunakan paper and pencil test (Asri Budiningsih, 2015). Evaluasi hasil belajar menuntut satu jawaban yang benar. Maksudnya, bisa siswa menjawab secara benar sesuai dengan keinginan guru, hal ini menunjukan bahwa siswa telah berhasil menyelesaikan tugas belajar nya. Evaluasi pembelajaran dalam pembelajaran konvensional dipandang sebagai bagian yang terpisah dari kegiatan pembelajaran dan biasanya dilakukan setelah selesai kegiatan pembelajaran.(Lubis et al., 2020).

\section{Pembelajaran Kritis Kreatif}

Paradigma teori kritis merupakan suatu mazhab dalam ilmu sosial yang meyakini bahwa sosial harus memainkan peranan yang signifikan dalam mengubah dunia dan meningkatkan kondisi kemanusiaan. Tujuan teori kritis adalah untuk mengaitkan antara teori dan praktik, memberi pandangan, dan memberdayakan subyek manusia (peserta didik) untuk mengubah situasi-situasi opresif yang mengatasi mereka (Kahpiana, 2016).

Teori kritik dapat digunakan dalam berbagai aspek kehidupan, salah satunya pendidikan. Lebih dari itu, teori kritis dalam pendidikan menjadi mazhab tersendiri yang mempunyai gagasan untuk memberdayakan kaum tertindas dan mentransformasikan ketidakadilan sosial yang terjadi di masyarakat melalui pendidikan. Menurut H.A.R. Tilaar, "pendidikan kritis secara informal dilahirkan dalam suatu konverensi universitas-universitas di Amerika Serikat pada tahun 1990-an di University of Illinois yang mengakui akan persamaan harkat manusia (peserta didik) yang tercetus di 
dalam berbagai aspek kehidupan manusia termasuk dalam pendidikan (Edi Subkhan, 2016).

Menurut Mansour Fakih, paradigma pendidikan kritis adalah mazhab pendidikan yang meyakini adanya muatan politik dalam segala aktivitas pendidikan. Aliran ini dalam diskursus pendidikan disebut juga "aliran kiriee karena orientasi politiknya yang berlawanan dengan mazhab liberal dan konservatif. Dalam konteks akademik, mazhab ini disebut dengan the sociology of education (pendidikan sosiologi) atau critical theory of education (kritik teori pendidikan).

Adapun pengertian pembelajaran kritis kreatif merupakan konsep di mana peserta didik dibimbing supaya dalam proses pembelajaran terjadi interaksi dua arah antara guru dan peserta didik. Hal tersebut dikarenakan dalam konsep pembelajaran kritis kreatif, guru dan peserta didik harus terlibat bersama-sama dalam knowledge production (Nuryatno, 2008:61), sehingga dalam paradigma pembelajaran kritis, peserta didik didorong sekaligus dibina supaya struktur sosial, ekonomi, budaya, agama, dan politik tidak diterima begitu saja, tetapi justru dipersoalkan, yakni pendidikan menolong peserta didik mengkritik kenyataan struktur yang tidak adil. Pembelajaran yang berpola kritis kreatif menjadikan prosesnya harus berjalan dengan kebijakan "learning process skill" dari pada "learning concept".

Pada pendekatan prosesnya, akan ditandai dengan model pembelajaran yang student center, bukan teacher center, yang dalam proses ini peserta didik menjadi manusia yang bisa mengarahkan dirinya sendiri, menjadi kritis, dan berpikir secara otonom (Nuryatno, 2008:62). Peserta didik juga perlu diarahkan menjadi bagian humaniora, yakni terus diajarkan makna wisdom (mendidik dan terdidik bagaimana menjadi manusia utuh) (Ichsan, 2019a). Peran guru lebih sebagai inspirator, korektor, informator, organisator, motivator, inovator, medaitor, fasilitator, pembimbing, pengelola kelas, supervisor, inisiator, dan evaluator yang bekerja keras untuk memberlakukan "dialog” sebagai ruh yang mendasari hidupnya proses pembelajaran, serta tidak mencoba menerapkan sikap "anti dialog" di dalamnya (Yarun; Khayati, 2018).

Proses pembelajaran yang bermodel seperti di atas memungkinkan munculnya sikap kritis kreatif pada peserta didik, di mana persepsi terhadap peserta didik tidak lagi dipandang sebagai bejana kosong yang harus dituangi air di dalamnya, tetapi sebagai subyek yang bersama-sama belajar dengan subyek yang mendidik untuk selalu berada dalam derap pencarian makna sesuatu kebenaran. Paradigma pembelajaran kritis sering disebut sebagai pembelajaran "produk kesadaran kritis".

Melihat dasar konsep filosofis dari pembelajaran kritis di atas, selanjutnya ada tiga ciri pokok pembelajaan kritis yaitu: Pertama, belajar dari realitas atau pengalaman. Kedua, tidak menggurui. Ketiga, dialogis. (Bahri \& Supahar, 2019). Dialog antara guru dan peserta didik harus bersandarkan pada etika-etika ilmiah, yang tidak menimbulkan kesenjangan antara seorang guru dan peserta didik. Hal tersebut 
Hikmah, Vol. 18, No. 1, Januari-Juni 2021, p-ISSN: 1829-8419 e-ISSN: 2720-9040

karena dialog mengandaikan kesadaran dan kerendahan hati, yaitu kemauan belajar dari orang lain meskipun menurut perasaan budaya dianggap lebih rendah, memperlakukan orang lain sederajat dan keyakian orang lain dapat mengajar kita. Dialog juga harus bersandar pada cinta kasih antara seorang guru dengan peserta didik.

Pembahasan tentang pembelajaran kritis ini akan dipaparkan melalui komponen-komponen yang ada.

- Peserta didik

Pembelajaran kritis memandang peserta didik bukan lagi sebagai "cawan" (yang pasif dan dituangi air ke dalamnya), tetapi sebagai subjek yang belajar dan bersama-sama dengan subjek yang mendidik untuk selalu berada dalam derap pencarian makna sesuatu kebenaran. Dalam pandangan seperti itu, sejak awal peserta didik menurut pandangan pembelajaran kreatif telah siap dan mampu menerima serta mengalami proses pembelajaran sebagai wacana untuk tumbuh dan berkembang kearah yang lebih maju dan dinamis. Proses pembelajaran dalam pembelajaran kritis kreatif mengimplikasikan sebuah usaha untuk memperoleh pengetahuan, maka para peserta didik sejak awal telah memposisikan diri sebagai objek pembelajaran yang kritis kreatif.

- Materi Pembelajaran

Pembelajaran kritis kreatif memandang materi pembelajaran yang dipilih harus sistematis, sejalan dengan tujuan yang telah dirumuskan, terjabar, relevan dengan kebutuhan peserta didik, sesuai dengan kondisi masyarakatsekitar, mengandung segi-segi etik, tersusun dalam ruang lingkup yanglogis, dan bersumber dari buku-buku yang terpercaya dan diakui. Agar dapat sesuai dan sejalan dengan kondisi peserta didik maka melibatkan peserta didik dalam menentukan materi pelajaran sangatlah perlu, hal ini dilakukan agar penmbelajaran lebih bermakna bagi peserta didik dan agar mereka paham dengan realitas hidup yang sebenarnya.

- Guru

Pembelajaran kritis kreatif memandang guru sebagai makhluk yang utuh, yang memiliki peranan dalam proses pembelajaran di antaranya adalah sebagai fasilitator, pembimbing, komunikator, transformator, manajer, dan evaluator (Kanzunnudin, 2013). Bersandar pada bagaimana cara pandang pembelajaran kritis kreatif terhadap keberadaan guru sebagai pemimpin bagi peserta didiknya, guru dalam pembelajaran kritis kreatif dianggap sebagai mahluk yang mampu mengemas pembelajaran secara kritis kreatif dan menyenangkan.

- Tujuan Pembelajaran

Adapun tujuan pembelajaran kritis kreatif justru hadir dengan tujuan membangkitkan kesadaran peserta didik untuk peduli dan kritis terhadap segala persoalan yang terjadi di lingkungan mereka. Belajar dalam realitas kehidupan merupakan hal yang sangat vital bagi peserta didik untuk mengetahui lingkungan dan memperoleh 
pengetahuan baru yang dapat menunjang perkembangan, baik fisik maupun mental.

Tujuan belajar pada model pembelajaran kritis kreatif tidak lepas dari hal-hal yang bersifat praktis untuk memecahkan suatu permasalahan yang berkaitan dengan efektivitas dalam pembelajaran. Pembelajaran kritis kreatif dalam konteks yang demikian, bertujuan menemukan jalan baru yang lebih baik dan beradab dalam sebuah upaya pemberdayaan dan pendidikan masyarakat.

- Metode Pembelajaran

Pembelajaran kritis kreatif berusaha agar peserta didik dapat memahami maksud atau makna terhadap materi yang telah dipelajari. Pembelajaran kritis kreatif yaitu berusaha memacu proses pembelajaran dengan mendorong aktivitas kreatif serta mengekspresikan bahan pembelajaran dengan sudut pandang peserta didik. Hal ini seperti metode dialog, diskusi, bertanya, dan inquiri (Kadek Hengki Primayana, 2019).

- Media Pembelajaran

Pembelajaran kritis kreatif memandang bahwa adanya media pembelajaran guna untuk sebagai alat membangkitkan semangat perhatian dan motivasi peserta didik, melibatkan keaktifan peserta didik, memberikan umpan balik dan penguatan atas materi yang telah pelajari. Guru menggunakan media bukan semata-mata karena media efektif membantu proses pemahaman, tetapi penggunaan media merupakan sebuah keharusan dalam rangka memproduksi pengetahuan. Bagi seorang guru, media bukan hanya berfungsi sebagai ilustrasi, tetapi lebih sebagai ajakan peserta didik untuk berpikir tentang sesuatu, mendiskusikan bersama, dan berdialog untuk menemukan kesimpulan dan jawabannya.

- Evaluasi Pembelajaran

Pembelajaran kritis kreatif memandang evaluasi pembelajaran sebagai sebuah proses yang sangat berkaitan dengan berlangsungnya proses pembelajaran. Dalam bahasa yang lain, evaluasi tidak berhenti pada saat akhir berakhirnya bahan ajar atau disebut dengan UAS (Ujian Akhir Semester), atau hanya berkisar pada sisi kognitif saja, melainkan peroses evaluasi tetap dinilai secara keseluruhan, baik hasil yang didapatkan waktu ujian akhir maupun keaktifan peserta didik di dalam kelas sewaktu proses belajar mengajar sedang berlangsung. Dalam istilah yang lain, evaluasi dalam pembelajaran kritis kreatif melibatkan beberapa aspek, yaitu: kognitif, afektif, dan psikomotorik. Ketiga hal tersebut termasuk dalam proses evaluasi setelah melewati proses pembelajaran.

\section{Pembelajaran Konvensional dan Pembelajaran Kritis Kreatif dalam perspektif Pendidikan Islam}

Sebagai satu disiplin ilmu, pendidikan Islam memiliki tujuan yang mulia yaitu menciptakan peserta didik yang beriman dan bertakwa kepada Allah serta membina, membimbing, dan mendorong peserta didik 
Hikmah, Vol. 18, No. 1, Januari-Juni 2021, p-ISSN: 1829-8419 e-ISSN: 2720-9040

dalam memanfaatkan segala macam potensi bawaannya agar dapat bekerja secara maksimal berdasarkan kebutuhankebutuhan yang diinginkan. Tujuan ini akan dapat terealisasi dengan baik jika salah satu komponen dalam pembelajaran seperti guru bekerja dengan sungguh-sungguh.

Berdiri sebagai objek yang memandang peserta didik sebagai objek sekaligus subyek dalam proses pembelajaran. Kehadiran guru dalam proses pembelajaran lebih sebagai motivator, pembimbing, pengatur, dan pengarah bagi terciptanya pembelajaran yang menyenangkan dan mencerahkan (Hidayah, 2020).

Dalam uraian sebelumnya, peneliti sudah mengklasifikasikan secara teoritis bahwa model pembelajaran secara umum terbagi menjadi dua yaitu model pembelajaran konvensional dan pembelajaran kritis kreatif. Dalam perspektif pendidikan Islam, kedua model pembelajaran ini tentu memiliki perbedaan yang signifikan. Kelemahan dan kekurangan antara dua model pembelajaran ini berjalan beriringan dengan kelebihan yang dimilikinya. Peserta didik dalam kaca mata pembelajaran konvensional bukanlah objek pendidikan yang memiliki potensi untuk bisa berkembang secara mandiri melainkan ia memandang bahwa peserta didik bagian dari pembelajaran yang hanya menerima ujaran dan perintah dari seorang guru. Adapun pembelajaran kritis kreatif memandang peserta didik sebagai objek sekaligus subjek pendidikan yang memiliki potensi alamiah yang harus dikembangkan oleh seorang guru lewat proses pembelajaran yang membuka ruang bagi peserta didik untuk mengelaborasikan pendapat serta mengembangkan kemampuannya dalam melihat realitas sosial, sehingga menjadi manusia-manusia solutif di tengah persoalan sosial yang semakin 'menggurita'.

Perbedaan cara pandang antara kedua model pembelajaran di atas dalam memandang peserta didik sangat mudah kita dapatkan sisi perbedaannya. Model pembelajaran konvensional cukup kaku dalam memandang keberadaan peserta didik dalam proses pembelajaran. Begitupun sebaliknya, pembelajaran kritis kreatif cukup apresiatif dalam memandang peserta didik. Maka dalam konteks ini, pendidikan Islam memandang bahwa kedua model pembelajaran di atas sama-sama memiliki kekurangan dan kelebihannya. Dalam perspektif pendidikan Islam, model pembelajaran konvensional, walaupun terkesan kaku dalam melihat peserta didik, tetapi yang perlu diapresiasi adalah bagi peserta didik yang tipologi belajarnya auditori akan mudah mencerna materi pelajaran. Mereka akan senang menjalani proses pembelajaran yang lebih menekankan pada indra pendengar. Bagi mereka, mendengar adalah cara belajar yang asik dan efektif.

Berkaitan dengan hal di atas, bukankah dalam pendidikan Islam memiliki tujuan mulia, yaitu untuk mendorong potensi alamiah yang dimiliki oleh peserta didik lewat proses pembelajaran tanpa melihat, memilih, dan memilah peserta didik itu berkarakter auditori atau bukan. Karena bagaimanapun pendidikan Islam 
bertujuan untuk menciptakan manusia yang utuh dan lengkap, yang dapat merealisasikan tugas dan fungsinya sebagai khalifatullah (pemimpinan di muka bumi) dan abdullah (hamba Tuhan).

Dalam sisi inilah, kehadiran model pembelajaran konvensional menjadi penting. Karakter pembelajaran konvensional lebih memberdayakan peserta didik yang memiliki keunggulan dalam model pembelajaran auditori yang tidak begitu diperhatikan oleh model pembelajaran kritis kreatif, karena ia lebih pada bagaimana mengasah lebih tajam cara berpikir maupun cara belajar peserta didik yang lebih mengandalkan kemampuan berfikir logis. Demikian pula dengan komponen pembelajaran yang lain, seperti materi pembelajaran, guru, tujuan pembelajaran, metode pembelajaran, evaluasi pembelajaran. Perbedaan dalam memandang komponen pembelajaran tersebut menjadi sebuah keniscayaan yang tidak dapat dihindari oleh kedua model pembelajaran di atas.

Hal yang lebih memperjelas sisi perbedaaan antara pembelajran konvensional dan pembelajaran kritis kreatif adalaha definisi tentang guru. Menurut pembelajaran konvensional, guru merupakan objek yang memberikan sesuatu kepada peserta didik, yakni hanya sekedar memindahkan atau mentransfer ilmu pengetahuan yang harus dicatat dan dihafal oleh peserta didik. Sedangkan pembelajaran kritis krearif beranggapan bahwa guru merupakan subyek yang mendorong terbentuknya manusia (peserta didik) yang beriman, cerdas, kritis kreatif, dan memiliki keluhuran budi pakerti.

Pembelajaran kritis kreatif juga memandang sosok guru yang tidak hanya bertumpu pada transfer pengetahuan saja, tetapi juga transfer nilai (Ichsan, 2019b). Pembelajaran kritis kreatif juga menegasikan akan pola pembelajaran yang hanya berpusat pada guru (teacher centered), tetapi lebih pada pola pembelajaran yang memberikan ruang bagi peserta didik untuk lebih mengaktualisasikan potensi akademisnya secara maksimal.

Dalam perspektif pendidikan Islam, pembelajaran kritis kreatif memang cukup efektif untuk diterapkan di era kekinian berdasarkan beberapa alasan, yaitu: Pertama, memberikan ruang yang cukup luas bagi peserta didik dalam memanfaatkan potensi laten yang dimiliki. Kedua, mendorong peserta didik untuk selalu berpikir logis dengan menjadikan guru sebagai tokoh dalam memberikan stimulus bagi lahirnya dialog dalam proses pembelajaran. Ketiga, kepercayaan diri peserta didik untuk berekspresi menyampaikan pendapat di depan guru, teman-temannya sangat memungkinkan untuk terciptanya identitas anak (peserta didik).

Ketiga alasan ini dapat dibenarkan karena kondisi generasi kekinian semakin mudah dalam mengakses informasi. Namun pendidikan Islam memandang bahwa pembelajaran konvensional tidak bisa ditinggalkan secara keseluruhan, karena bagaimanapun metode ceramah, dalam istilah yang lain ekspositori, yaitu sama- 
Hikmah, Vol. 18, No. 1, Januari-Juni 2021, p-ISSN: 1829-8419 e-ISSN: 2720-9040

sama memiliki makna pada proses pembelajaran yang berpusat pada guru, menggunakan cara hafalan dalam proses pembelajaran tetap dibutuhkan oleh guru untuk memperkaya metode pengajarannya. Hal tersebut dikarenakan adanya beberapa mata pelajaran yang menuntut peserta didik untuk menghafal seperti rumus-rumus dalam mata pelajaran Matematika, Fisika, Kimia, dan teori-teori Geografi, bahkan dalam mata pelajaran agama (seperti ayatayat al-Qur'an maupun hadist) yang tentu harus dihafalkan serta dipahami maksudnya bagi diri masing-masing peserta didik.

Dengan demikian, kedua model pembelajaran tersebut harus dapat diupayakan untuk diterapkan secara bergantian sesuai dengan kebutuhan materi atau mata pelajaran, sehingga tujuan pendidikan yang sesungguhnya dapat direalisasikan dengan terciptanya peserta didik yang cerdas dalam berpikir, beriman, dan berislam dengan sungguh-sungguh serta berbudi pakerti yang luhur. Dalam konteks ini, keberadaan guru sebagai fasilitator menjadi sangat urgen, di mana guru dituntut untuk bekerja secara maksimal dalam mengawal, membimbing, serta menyelaraskan metode yang akan digunakan dalam proses pembelajaran. Dengan hal itu, komunikasi guru dan peserta didik menjadi harmonis dan berkembang sampai pada taraf dialog yang mengisyaratkan adanya proses pertukaran ide, gagasan, serta pengalaman dari seorang guru kepada peserta didik dan begitupun sebaliknya.

\section{Komparasi pembelajaran konvensional dan kritis kreatif}

Matriks temuan penelitian dipaparkan pada tabel berikut ini:

Tabel 1. Komparasi Pembelajaran

\begin{tabular}{|c|c|}
\hline Konvensional & Kritis-kreatif \\
\hline $\begin{array}{lr}\text { Peserta didik } \\
\text { Peserta didik objek } \\
\text { pasif sekaligus } \\
\text { penurut remua } \\
\text { perlakuan guru }\end{array}$ & $\begin{array}{l}\text { Peserta didik } \\
\text { Peserta didik sebagai } \\
\text { objek yang aktif } \\
\text { dalam pembelajaran }\end{array}$ \\
\hline $\begin{array}{ll}\text { Guru } & \\
\text { Guru } & \text { sosok } \\
\text { kharismatik } & \end{array}$ & $\begin{array}{l}\text { Guru } \\
\text { Sebagai Pembimbing } \\
\text { Sebagai fasilitator } \\
\text { Seabgai Evaluator } \\
\text { Sebagai transformator } \\
\end{array}$ \\
\hline $\begin{array}{l}\text { Materi Pelajaran } \\
\text { materi } \\
\text { disampaikan sesuai } \\
\text { dengan urutan isi } \\
\text { buku teks }\end{array}$ & $\begin{array}{lr}\text { Materi Pelajaran } \\
\text { Materi pembelajaran } \\
\text { harus sistematis, } \\
\text { sejalan dengan } \\
\text { tujuan yang telah } \\
\text { dirumuskan, terjabar, } \\
\text { relevan dengan } \\
\text { kebutuhan }\end{array}$ \\
\hline $\begin{array}{ll}\text { Metode } & \\
\text { Pembelajaran } & \\
\text { Metode } & \\
\text { pembelajaran yang } \\
\text { dikenal lebih } \\
\text { banyak berpusat } \\
\text { pada guru }\end{array}$ & $\begin{array}{l}\text { Metode Pembelajaran } \\
\text { Metode fokus pada } \\
\text { peserta didik agar } \\
\text { memahami maksud } \\
\text { atau makna terhadap } \\
\text { materi yang telah } \\
\text { dipelajari }\end{array}$ \\
\hline 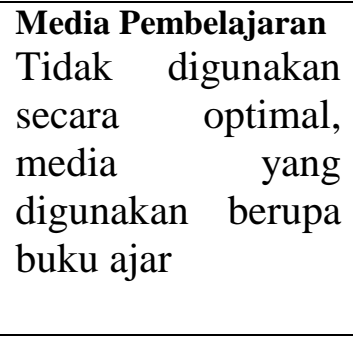 & $\begin{array}{l}\text { Media Pembelajaran } \\
\text { Sebagai pembangkit } \\
\text { semangat perhatian } \\
\text { dan motivasi peserta } \\
\text { didik, melibatkan } \\
\text { keaktifan peserta } \\
\text { didik, }\end{array}$ \\
\hline $\begin{array}{l}\text { Evaluasi Pembelajaran } \\
\text { Evaluasi pada } \\
\text { aktivitas respon } \\
\text { pasif, keterampilan } \\
\text { secara terpisah. }\end{array}$ & $\begin{array}{l}\text { Evaluasi Pembelajaran } \\
\text { Evaluasi secara } \\
\text { keseluruhan, baik } \\
\text { hasil yang } \\
\text { didapatkan waktu } \\
\text { ujian akhir maupun } \\
\text { keaktifan peserta } \\
\text { didik }\end{array}$ \\
\hline
\end{tabular}




\section{SIMPULAN}

Model pembelajaran konvensional lebih memusatkan keaktifan guru dibandingkan keaktifan peserta didik (teacher centered), sedangkan model pembelajaran kritis kreatif menekankan pada terjadinya interaksi dua arah antara guru dan peserta didik. Pendidikan Islam memandang pembelajaran konvensional merupakan model pembelajaran yang fokus mendorong peserta didik yang suka belajar auditori, sedangkan pembelajaran kritis kreatif menurut pendidikan Islam adalah model pembelajaran yang berusaha memberdayakan peserta didiknya menjadi kritis dalam berpikir dan kreatif dalam proses dialog, serta adanya keterlibatan peserta didik pada saat proses belajar mengajar. Maka dari itu, di tengah perbedaan antara kedua model pembelajaran tersebut, pendidikan Islam memandang bahwa perlu ada upaya penyatuan, atau paling tidak memanfaatkan kedua model pembelajaran tersebut sesuai dengan kebutuhan dalam proses pembelajaran tanpa ada yang harus dipinggirkan satu sama lain.

\section{DAFTAR PUSTAKA}

A Yarun; N A Khayati. (2018). Relevansi Pendidikan Kritis dengan Metode Pengajaran Ibnu Khaldun pada Generasi Milenial. Al Ghazali, 10(2).

Adnan, M. (2015). Paradigma Pendidikan Kritis dalam Perspektif Pendidikan Islam. Cendekia: Jurnal Studi Keislaman, 1(1), 97-117. https://doi.org/10.37348/cendekia.v1i1. 7

Asri Budiningsih. (2015). Belajar dan Pembelajaran. PT. Rineka Cipta.
Azmi, S. N. (2012). Perbandingan antara Model Pembelajaran Cooperative Learning Tipe STAD dengan Pembelajaran Konvensional dalam Rangka Meningkatkan Hasil Belajar PAI (Eksperimen kelas XI SMA Negeri 3 Tangerang) [UIN Syarif Hidayatullah]. https://repository.uinjkt.ac.id/dspace/ha ndle/123456789/4576

Bahri, F. M., \& Supahar, S. (2019). Kemampuan Berpikir Kritis Menggunakan Tes Terintegrasi Agama dan Sains dalam Pembelajaran Pai Di SMA. Edukasi Islami: Jurnal Pendidikan Islam, 8(2), 233-252.

Bashori. (2016). Penerapan Model Pembelajaran Artikulasi dalam Meningkatkan Hasil Belajar Al-Qur'an Hadits (Studi pada Siswa Kelas VII B di MTs Thamrin Yahya Rambah Hilir). Hikmah: Jurnal Pendidikan Islam, $5(2)$.

E. Mulyasa. (2007). Standar Kompetensi dan Sertifikasi Guru. Rosdakarya.

Edi Subkhan. (2016). Pendidikan Kritis. ArRuzz Media.

Fahrudin \& Ahmad Shofiyuddin Ichsan. (2020). Islamisasi Ilmu sebagai Identitas Keagamaan (Telaah Kritis Syed Naquib Al-Attas). Alfuad: Jurnal Sosial Keagamaan, 4(1), 73.

Faizal Djabidi. (2016). Unsur-Unsur Filsafat Yunani dan Relevansinya dengan Pendidikan Agama Islam. Adz-Zikr: Jurnal Pendidikan Agama Islam, 1(1).

Gozali, M., \& Tamrin, M. (2020). Peranan Pimpinan dan Guru dalam Pembinaan Akhlak Siswa pada Madrasah Tsanawiyah Negeri Kupang. Hikmah, $17(1)$, 26-33. https://doi.org/10.53802/hikmah.v17i1. 79

H Hidayah. (2020). Peningkatan Kedisiplinan Waktu Kehadiran Guru 
Hikmah, Vol. 18, No. 1, Januari-Juni 2021, p-ISSN: 1829-8419 e-ISSN: 2720-9040

dan dalam Melaksanakan Kegiatan Pembelajaran Melalui Penerapan Reward dan Punishment di SD Negeri 1. Jurnal Serambi Akademica, 6(1).

Helmiati. (2016). Model Pembelajaran. Aswaja Pressindo.

Hidayatullah, F. B. C. R. S. H. (2015). Pengaruh Model Pembelajaran Kooperatif Tipe Jigsaw dan Kecerdasan Emosional terhadap Hasil Belajar. JTPPm (Jurnal Teknologi Pendidikan Dan Pembelajaran), 2(2).

Huda, M. (2015). Peran Pendidikan Islam Terhadap Perubahan Sosial. Edukasia: Jurnal Penelitian Pendidikan Islam, 10(1), 165-188. http://dx.doi.org/10.21043/edukasia.v1 $0 \mathrm{i} 1.790$

Ichsan, A. S. (2019a). Konstruksi Pendidikan Relasi Kiai dan Santri di Pondok Pesantren Lintang Songo Piyungan Yogyakarta. Jurnal Darussalam: Jurnal Pendidikan, Komunikasi dan Pemikiran Hukum Islam, 11(1), 199-221. https://doi.org/10.30739/darussalam.v1 $1 \mathrm{i} 1.458$

Ichsan, A. S. (2019b). Revisiting the Value Education in the Field of Primary Education (A Study on Abdurrahman An-Nahlawi's Perspective). Elementary: Jurnal Ilmiah Pendidikan Dasar, 5(1).

Kadek Hengki Primayana. (2019). Menciptakan Pembelajaran Berbasis Pemecahan Masalah dengan Berorientasi Pembentukan Karakter untuk Mencapai Tujuan Higher Order Thingking Skills (HOTS) pada Anak Sekolah Dasar. Purwadita: Jurnal Agama Dan Budaya, 3(2).

Kahpiana. (2016). Epistemologi Mazhab Pendidikan Kritis dalam Perspektif Islam. Al-Tazkiyy, 13(1).

Kanzunnudin, M. (2013). Karakter Guru dalam Perspektif Holistik. Universitas Muria Kudus.

Khasanah, N. (2017). Penerapan Model Pembelajaran Aktif, Inovatif, Kreatif, Efektif, dan Menyenangkan (PAIKEM) dalam Pembelajaran PAI Kelas $X$ di SMA Negeri 6 Samarinda [IAIN Samarinda]. http://repository.iainsamarinda.ac.id/handle/123456789/636

Lubis, R. R. (2016). Kompetensi Kepribadian Guru dalam Persfektif Islam (Studi Pemikiran Nasih 'Ulwān dalam Kitab Tarbiyatul Aulād). Tazkiya, 5(2), 1-13. http://jurnaltarbiyah.uinsu.ac.id/index.p hp/tazkiya/article/viewFile/83/67

Lubis, R. R., Enita, P., Marpaung, M. A. F., \& Harahap, R. (2020). Model Evaluasi Pembelajaran PAI Berbasis Daring Di MTs. Usman Syarif Medan Selama Pandemi Covid-19. El-Buhuth: Borneo Journal of Islamic Studies, 3(1), 3953. https://doi.org/10.21093/elbuhuth.v3i1.2633

Manurung, P. (2020). Pemanfaatan Sumber Belajar dalam Bidang Bimbingan dan Konseling. Hikmah, 17(2).

Marzuki, A. (2017). Model-Model Pembelajaran PAI Inovatif dan Kontekstual. Al-Ghazwah, 1(1), 103116.

Mesiono, M., \& Haidir, H. (2021). Manajemen Pembiayaan Pendidikan (Analisis Konsep dan Implikasinya Terhadap Peningkatan Mutu Pendidikan). Hikmah, 17(2), 61-73. https://doi.org/10.53802/hikmah.v17i2. 88

Muhammad Munif. (2016). Pengembangan Pendidikan Agama Islam sebagai Budaya Sekolah. Pedagogik: Jurnal Pendidikan, 3(2).

Muzayyin Arifin. (2014). Filsafat Pendidikan Islam. PT. Bumi Aksara.

Nuryatno, M. A. (2008). Mazhab 
Pendidikan Kritis, Menyingkap Relasi Pengetahuan Politik dan Kekuasaan. Resist Book.

Nurzakiyah, N. (2017). Strategi Pembentukan Karakter Peserta Didik di SMP Negeri 3 Mapilli Kec. Mpilli Kab. Polewali Mandar. Universitas Islam Negeri Alauddin Makassar.

Rahardjo, D. I. (2015). Pengaruh strategi pembelajaran (tematik versus konvensional) dan gaya kognitif terhadap prestasi belajar siswa kelas III Sekolah Dasar. Universitas Negeri Malang.

Ridwan, S., Ag, S., \& Pd, M. I. (2015). Media Pembelajaran Berbasis Teknologi pada Mata Pelajaran PAI. 40-53.

Rustam \& Ahmad Shofiyuddin Ichsan. (2020). Pendidikan Islam Berbasis Kearifan Lokal. IQRO: Journal of Islamic Education, 3(1).

Sahkholid Nasution. (2012). Metode Konvensional dan Inkonvensional dalam Pembelajaran Bahasa Arab. Didaktika, 12(2).

Sapiudin, S., Nata, A., \& Syihab, U. (2016). Model Pembelajaran Ilmu Ushûl Fiqh di Jurusan Pendidikan Agama Islam (Analisis Penerapan Model Pembelajaran Konvensional dan Pembelajaran Berbasis Masalah). Ta'dibuna, 5(1), 60-83. https://core.ac.uk/download/pdf/23080 7662.pdf

Siregar, N. N. (2019). Perbedaan Hasil Belajar Matematika dan Motivasi Belajar Siswa dengan Menggunakan Pendekatan Matematika Realistik dan Pendekatan Konvensional. Ittihad: Jurnal Pendidikan, 3(1).

Sugiyono. (2016). Memahami Penelitian Kualitatif. Alfabeta.

Sunaryo, Y. (2014). Model pembelajaran berbasis masalah untuk meningkatkan kemampuan berpikir kritis dan kreatif matematik siswa sma di kota tasikmalaya. Jurnal Pendidikan Dan Keguruan, 1(2), 209679.

Umam, M. K. (2019). Studi komparatif paradigma teori belajar konvensional barat dengan teori belajar islam. AlHikmah: Jurnal Kependidikan Dan Syariah, 7(2), 57-80. http://jurnal.staiba.ac.id/index.php/AlHikmah/article/view/100

Wina Sanjaya; Andi Budimanjaya. (2017). Paradigma Baru Mengajar. Kencana.

Yekti Prasetyasni; Syamsu Hadi; Marimin. (2012). Perbedaan Penerapan Model Pembelajaran Quantum Teaching dengan Metode Konvensional dalam Hasil Belajar Siswa. Economic Education Analysis Journal, 1(2).

Zainuddin, M. R. (2014). Pengembangan Kreativitas Siswa dalam Pembelajaran Pendidikan Agama Islam melalui Belajar Kelompok. Edukasi: Jurnal Pendidikan Islam (e-Journal), 2(1), 486-598. http://orcid.org/0000-00026579-0109

Zikri. (2016). "Wooden House" sebagai Media Pembelajaran Introduksi Bangun Ruang dengan Pendekatan Saintifik untuk Meningkatkan Pemahaman Konsep Matematika Kelas VIII-I SMP Negeri 1 Labuhanhaji Timur. Jurnal Pendidikan Matematika, $3(1)$. 